\title{
Global Organization of Innovation and Cooperability in Brazilian Multinationals
}

\author{
Priscila Rezende da Costa ${ }^{1 *}$, Geciane Silveira Porto ${ }^{2}$, Simone Vasconcelos Ribeiro Galina ${ }^{2}$, \\ Marcos Roberto Piscopo ${ }^{1}$, Emerson Antonio Maccari ${ }^{1}$
}

\begin{abstract}
Understanding the dissipation of innovations is necessary to develop them, as a company on its own does not have all the capabilities that it needs. On the contrary, they are increasingly spread over internal and external contexts, and are not developed in isolation. Most of the time, they depend on interactive, innovative processes in a global context. The aim of this study is to evaluate how the global organizational structure of innovation affects the dynamic capability of cooperation (cooperability) in Brazilian multinationals (BMNs). To achieve this goal, we conducted a survey of BMNs, and a final sample of 60 companies answered a structured questionnaire. We performed statistical tests such as Factor Analysis, Cronbach's Alpha, Multiple Regression and Hierarchical Cluster, and cross-analysis of quantitative results that enabled us to create a Cooperability Model, that is, a model of local, international and global development for a dynamic capability of cooperation in BMNs. The results show that technological strengths of foreign subsidiaries and the reverse transfer of their capabilities to the parent company and technology partners affect the dynamics of cooperation in BMNs (inputs and results of cooperability). Furthermore, we detected an inverse relationship between the autonomy of foreign subsidiaries and the dynamic of cooperation in BMNs.
\end{abstract}

Keywords: Cooperability; Innovation; Dynamic Capability; Brazilian Multinationals.

Submitted: July $1^{\text {st }} 2016 /$ Approved: January $26^{\text {th }} 2017$

\section{Introduction}

In recent years, markets have become more and more dynamic, and new forms of competition have appeared. Therefore, companies have to adapt to the new landscape, explore changes in their business environments, and seek opportunities to devise new technological and strategic cycles (McMahon and Thorsteinsdóttir, 2013; Teece, 2007). Experiencing and exploring changes is a challenge that companies face to remain operational. Nevertheless, to survive and succeed under changing conditions, companies must develop dynamic capabilities to create, expand and modify the ways in which they survive (Hanaki et al., 2010; Helfat et al., 2009).

To develop dynamic capabilities, especially those related to innovation, it is necessary to understand how they are distributed (Hanaki et al., 2010). This means that a company on its own does not have all the capabilities it requires, as it is increasingly common to find spread over internal and external business environments. They do not develop in isolation and usually depend on innovative processes that interact globally (Helfat et al., 2009).

The current challenge does not rely exclusively on generating product and process innovation locally, but on building dynamic capabilities to create innovative solutions and new business models on local and global scales. In this sense, the competitive challenge of cooperability (i.e., the intentional capability of dynamically developing cooperative projects in which partners create and share technological and innovative resources in local and/or global contexts) is the sustainable creation of competitive advantages of innovation that are distinct and difficult to replicate. Hence, dynamic capabilities are particularly important since the current stock of resources is less important than the capacity to accumulate and combine new resources both internally and externally - mainly if these interactions can contribute to building singular skills in $\mathrm{R} \& \mathrm{D}$, new product development, technological innovation and others (Doz et al., 2001).

Cooperability is a challenging and complex process for multinationals from emerging economies since they are usually newcomers and compete against multinationals from advanced economies that already dominate global markets. Therefore, unlike the incumbents, new multinationals must develop and systematize global innovation, including the reverse transfer of capabilities from foreign subsidiaries to headquarters and technological partners, and give them autonomy to develop their scientific attributes.

It should be emphasized that recent discussions have highlighted academic challenges regarding the organizational arrangements established by multinationals and their subsidiaries and external partners, including technological agility, responsiveness, load-balancing innovation and efficiency, environmental sensitivity and, specifically, the sharp increase in cooperation. This shows a trend of involvement between actors with unique skills that are shifting the locus of work previously defined as the core of the company (such as innovation) outside its borders (Gulati; Puranam \& Tushman, 2012). Thus, the theoretical gap is concerned with scientific discussions and the development of analytic models on the importance of cross-border

(1) Programa de Mestrado e Doutorado em Administração da Universidade Nove de Julho (PPGA-UNINOVE), Brazil

(2) Faculdade de Economia, Administração e Contabilidade de Ribeirão Preto (FEA-RP/USP), Brazil

*Corresponding author: priscilarezende@yahoo.com.br 
coordination. This is because organizational structure theories tend to emphasize intrafirm dimensions and formal authority (Gulati; Puranam \& Tushman, 2012), in other words, dimensions that are discrete or foolishly absent in contexts of close collaboration between companies that are often geographically far apart and formally independent.

This article aims (a) to check whether the reverse transfer of capabilities from foreign subsidiaries to headquarters and technological partners affects cooperation in BMNs; (b) to determine if there is a connection between the autonomy of foreign subsidiaries and cooperation in BMNs; (c) to analyse if technological attributes of foreign subsidiaries determine the dynamic capability of cooperation in BMNs, and finally (d) to propose a model for the dynamics of cooperation in BMNs.

This article is relevant because of its empirical contributions to the theme of dynamic capabilities of cooperation and their association with the reverse transfer of capabilities between subsidiary and headquarters, the autonomy of foreign subsidiaries and their technological competence. The present article validates a multidimensional construct for cooperability. It is also worth noting that $60 \mathrm{BMNs}$ showed interest in taking part in this research. However, the sample represents $82 \%$ of the universe of these companies.

\section{Relational Capabilities and Globalization of Innovation}

Relational capabilities are the ones involved in the deliberate setting of interaction networks intended to accumulate and refine the company's resource base (Lorenzoni and Lipparini, 1999; Dyer and Kale, 2007; Schilke and Goerzen, 2010). They comprise technical and interpersonal skills necessary to manage the general alliancing process efficiently. They range from recognition of cooperation opportunities to evaluation and internalization of results in a continuous learning process and preferably formalized in a function/area, including procedure definition and coding related to implantation and process execution.

Developing relational capabilities is only possible by forming alliances focused on learning and achieving future returns. To manage an alliance network effectively, a company must acquire practical experience in this activity. Consequently, the company could develop terms of trade (access and transfer of knowledge and skills), choose a suitable governance structure for each alliance and extract value from internalized knowledge, among other competences (Dyer and Kale, 2007; Lorenzoni and Lipparini, 1999; Wuyts and Dutta, 2014). These capabilities create value due to the (Helfat et al., 2009; Schilke and Goerzen, 2010): (a) creation of assets inherent to these partnerships; (b) mutual access to complementary resources; (c) existence of a routinely substantial transfer of knowledge between partners; and (d) efficient governance mechanisms that can limit transaction costs between stakeholders (Table 1).

Relational capabilities require systematic actions not only through the careful selection of alliances but also through making investments and outlining deliberate cooperation strategies with external sources (Schilke and Goerzen, 2010). Moreover, the development of relational capabilities depends on a management process that involves (Leischnig et al., 2014): (a) efficient prospection of allies to ensure the effective interest during the partnership; (b) active contribution from partners; (c) setting a quality project management; (d) adjusting the objectives of stakeholders; (e) effective communication throughout the cooperation process; and (f) monitoring the alliance.

Within the context of relational capabilities, multinationals can be understood as coordinated systems or networks that 'create' value activities. Some of these activities are conducted within the hierarchy of the company and others through contracts and social relationships (Doz et al., 2001; Gibbons and Henderson, 2012). In this sense, a multinational cannot be defined only by the extension of its foreign production premises but by the sum of all of its internal and external activities that aggregate value (Andersson et al., 2007; Zaheer and Hernandez, 2011). As a result, multinationals are turning their structures into open and flexible networks with subsidiaries that generate and share knowledge in local and global contexts (Cantwell et al., 2010; Zohdi et al., 2013). Such structures require multinationals to disseminate and institutionalize the management process of cooperation relationships to create and continuously integrate the knowledge developed at headquarters, subsidiaries and alliances, both in local and global contexts (Dunning and Lundan, 2010; McMahon and Thorsteinsdóttir, 2013).

Table 1. Relational Capacity elements that create value.

\begin{tabular}{|l|l|}
\hline $\begin{array}{l}\text { Elements of Relational capacity to } \\
\text { generate value }\end{array}$ & Description \\
\hline $\begin{array}{l}\text { Creation of specific assets for the } \\
\text { partnership }\end{array}$ & $\begin{array}{l}\text { Companies create stronger relational skills when they find technological opportunities and highly complementary stra- } \\
\text { tegic partners. It should be noted that companies can improve the chances of identifying additional partners through } \\
\text { continuous prospecting and classification of new partners and the use of monitoring and evaluation of current ones. } \\
\text { Reputation and previous experience play an important role in this assessment. Moreover, interdependence between } \\
\text { partners is necessary to provide incentives for cooperation. A high level of dependence appears to be of particular im- } \\
\text { portance, especially when tacit knowledge is involved in the cooperation project. Thus, the interdependence between } \\
\text { partners should be considered by the partner in planning a cooperative project. }\end{array}$ \\
\hline $\begin{array}{l}\text { Mutual access to complementary } \\
\text { resources }\end{array}$ & $\begin{array}{l}\text { Enables the development and combination of appropriate structures to the relationship and the actors involved. Note } \\
\text { also that the creation of specific assets requires time and systematic investment in the partnership and the partner } \\
\text { institutions need to increase their specific assets to make the most of their relationships. Asset specificity may occur in } \\
\text { several ways, including local specificity, specialization of physical asset, and human asset specificity. Human co-exper- } \\
\text { tise allows partners to work together more efficiently and effectively, reducing communication errors and improving } \\
\text { the quality of the outcome of the relationship. }\end{array}$ \\
\hline
\end{tabular}




\begin{tabular}{|l|l|}
\hline $\begin{array}{l}\text { Substantial flow of knowledge transfer } \\
\text { between partners }\end{array}$ & $\begin{array}{l}\text { Refers to the existence of a regular model of interaction at business level, enabling the transfer, recombination or cre- } \\
\text { ation of knowledge. Effective knowledge transfer processes between the company and its partners need to be developed } \\
\text { and then institutionalized. The ability of a company to absorb knowledge from the partner depends on prior knowledge } \\
\text { or "absorptive capacity", which constitutes the ability of a company when it comes to organizing and assimilating new } \\
\text { knowledge, and then applying it for commercial purposes. }\end{array}$ \\
\hline Effective governance mechanisms & $\begin{array}{l}\text { Adoption of contracts or ownership structures that effectively protect each partner's opportunistic behavior. Formal } \\
\text { agreements must protect the interests of each side, so there will be a higher probability of relations based on equality, } \\
\text { given the existence of high levels of asset specificity on each side. The new element of effective governance assigned } \\
\text { stands for the importance of informal measures to protect the interests of each side against opportunism. The relation- } \\
\text { ship between evidence suppliers in Japan has shown high levels of effectiveness of the "trust and reputation" elements } \\
\text { to control of opportunistic behavior. }\end{array}$ \\
\hline
\end{tabular}

Source: Gibbons and Henderson (2012), Helfat et al. (2009), Leischnig et al., 2014, Petruzzelli (2011), Schilke and Goerzen, 2010, and Wuyts and Dutta (2014).

In response to the increasing need to balance the pressures of global integration and local responsiveness, foreign subsidiaries should play a prominent role in creating knowledge that is valuable to the MNE (multinational enterprise) as a whole (Rabbiosi, 2011; Zaheer and Hernandez, 2011). Teece (2014) claims that the proper integration of the R\&D units of a MNE may result not only in new products but also in organizational dynamic capabilities. Ester et al. (2010) argue that $\mathrm{R} \& \mathrm{D}$ internationalization has a positive influence on the development of dynamic capabilities.

According to Rabbiosi (2011) one of the principal managerial problems in MNEs is the balance between coordination mechanisms and knowledge transfers from subsidiaries to the parent company (known as reverse knowledge transfer) (Yang et al., 2008). The implementation of coordinating instruments in the parent company-subsidiary relationship, such as the decentralization of decision-making processes and communication mechanisms must be seen as a prior and fundamental element for reverse knowledge transfer (Rabbiosi, 2011). In this regard, a consensus has been reached in the literature as to the elements that could define global coordination and integration of subsidiaries. They include knowledge assets transfer, autonomy of the subsidiary and role of the subsidiary (Ambos and Schlegelmilch, 2007; Noorderhaven and Harzing, 2009; Keupp et al., 2011).

The transfer of knowledge assets is closely related to the appearance of a shared global knowledge base that creates mutuality and regular knowledge transfer among subsidiaries. Knowledge assets encompass information, know-how, practices, capabilities, technology and products (Yang et al., 2008) that when transferred can stimulate the development of skills that affect the subsidiary's performance (Mudambi and Navarra, 2004). Subsidiaries, in turn, can increase their bargaining and strategic influence power within the business network of a multinational. For that reason, understanding the following scenario is of great importance: does the reverse transfer of capabilities from foreign subsidiaries to headquarters affect a multinational's dynamic capability of cooperation, especially in the case of Brazilian multinationals? Thus, the following null hypothesis $\left(\mathrm{H}_{01}\right)$ is formulated: $\left(\mathrm{H}_{01}\right)$ Reverse transfer of capabilities from foreign subsidiaries to the headquarters and technological partners does not affect the dynamic capability of cooperation in BMNs.
The autonomy of the subsidiary is subdivided into two distinct categories: strategic and operational. Strategic autonomy is the capacity of a subsidiary to define its own agenda, whereas operational autonomy is the capacity of a subsidiary to manage the activities previously designated by the corporation (Nobel and Birkinshaw, 1998).

Authors such as Ambos and Schlegelmilch (2007) and Keupp et al. (2011) claim that strategic autonomy will negatively influence the performance of a subsidiary for two reasons. First, because the integration of highly independent subsidiaries tends to be smaller due to the coordination difficulties and this leads to the isolation of such subsidiaries. Second, resources of independent subsidiaries are likely to be less compatible with the stock of resources of the multinational's business network. Therefore, additional incentives and investments tend to be more controlled, which negatively affects the bargaining power and performance of the subsidiary (Zaheer and Hernandez, 2011).

The level of operational autonomy of a subsidiary reflects on the reach and extension of tasks set by the corporation. Subsidiaries with operational autonomy can take their own decisions regarding cooperation with external companies and other organizations. By doing so, they promote recognition and proper use of resources available through local innovation systems. Thus, the more operational autonomy a subsidiary has, the greater its ability to explore external innovation sources and improve both its resource base and performance. According to Teece (2014, p.26), "it is important to recognize that once a MNE creates a subsidiary that establishes its own networks and learning path, the subsidiary can accumulate specific assets and capabilities that can find useful application elsewhere". Operational autonomy must also offer the opportunity for subsidiaries to address problems creatively and stimulate creativity and organizational innovation (Ambos and Schlegelmilch, 2007), which leads us to formulate the following null hypothesis $\left(\mathrm{H}_{02}\right):\left(\mathrm{H}_{02}\right)$ There is no link between the autonomy of foreign subsidiaries and the dynamic capability of cooperation in BMNs.

When a subsidiary's role is strategically set by the multinational company, it is implied that it will perform certain activities on behalf of the corporation as a whole. As a result, responsibilities will have international rather than local implications. By performing activities with an international impact, a subsidiary can receive additional 
investments (Zaheer and Hernandez, 2011) and develop skills that are difficult to replicate. That will positively affect its bargaining power and performance (Mudambi and Navarra, 2004). Therefore, to understand whether the technological attributes of foreign subsidiaries define the dynamic capability of cooperation in a multinational, we formulated the following null hypothesis $\left(\mathrm{H}_{03}:\left(\mathrm{H}_{03}\right)\right.$ Technological attributes of foreign subsidiaries do not determine the dynamic capability of cooperation in BMNs.

Finally, there is the challenge of seeking full development of cooperation in companies from the institutionalization and management of relational capacity at headquarters and branches in a systematic and synergistic manner. For this purpose, we present a model of innovation that makes continuous use of internal and external sources of ideas and local and global knowledge, involving the transfer of resources, autonomy, technological attributes and overall structure of R\&D activities.

\section{Research Methodology}

We conducted a survey with 166 BMNs from industry, commerce and service sectors. All of them have production or commercial units overseas. We classified them to suit the scope of this study. We then identified which BMNs actually had international R\&D units or developed cooperative projects with foreign universities and research institutes in the last three years. This resulted in 73 BMNs that have internationalized their internal activities or R\&D cooperatives. Of these, $60 \mathrm{BMNs}$ were interested in taking part in the research. However, the sample represents $82 \%$ of the universe of these companies.

A structured questionnaire was applied to collect data from the sample of 60 BMNs. A 6-point Likert scale was used to obtain the opinions of the respondents regarding elements that define cooperation locally and globally. The questionnaire was made available both online and in .doc format to R\&D or Innovation executives and coordinators at their companies' headquarters. The data were analysed using bivariate and multivariate statistical techniques, processed by version 20.0 of SPSS software (Statistical Package for Social Sciences). Main Component, Cronbach's Alpha (Cronbach, 1951), Multiple Regression and Hierarchical Cluster statistical tests were used (Hair et al., 2005). Table 2, below, describes the dependent and independent variables used in the statistical tests and the research hypotheses.

Table 2. Variables and research hypotheses.

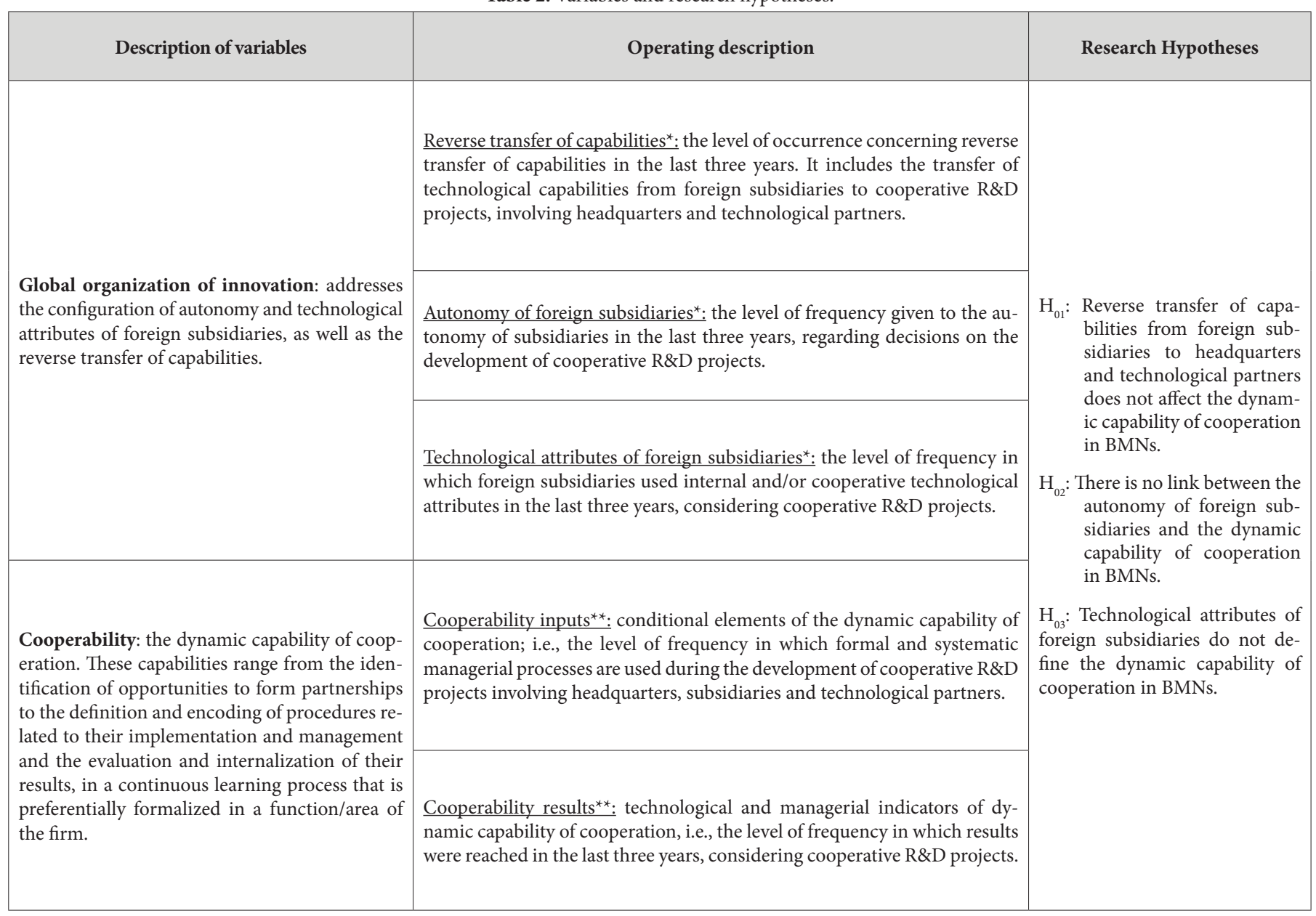

Key to table: ${ }^{\star}$ Independent variables, ${ }^{\star \star}$ Dependent variables. 


\section{Results}

In this study, $75 \%$ of the BMNs are industries, while $23 \%$ stand for service providers and only $4 \%$ are commercial companies. Moreover, we found that $52.5 \%$ employ over 500 people. As to the nature of technology partners of the BMNs, we observed that domestic clients (32.5\%) were more relevant regarding innovations, along with Brazilian Universities and Research Institutes (30\%). This is evidence that companies still use traditional sources of innovation entailing cooperation mechanisms that may have already been institutionalized.

To obtain a better fit for the regression models, we previously conducted the factor analysis of dependent and independent variables. We detected three factors (Table 3) that explain $82 \%$ of the variance of the responses on the independent variable of the global organization of innovation with
$1 \%$ significance. We arrived at the following classification: (Factor 1) reverse transfer of capabilities; (Factor 2) autonomy of foreign subsidiaries; and (Factor 3) technological duties of foreign subsidiaries.

The highest degree of explanation is for Factor 3 (50\%), i.e., the degree of frequency which foreign subsidiaries have been developing internal R\&D activities in the past three years, considering cooperative $\mathrm{R} \& \mathrm{D}$ projects. Factor 1 refers to the occurrence of reverse transfer of capabilities in the last three years, including the transfer of technological capabilities of foreign subsidiaries for cooperative R\&D projects, involving headquarters and technology partners. Factor 2 stands for the frequency which autonomy was granted to foreign subsidiaries in the last three years regarding the decisions involved in the development of cooperative projects of R\&D with the same degree of explanation (16\%) (Table 3).

Table 3. Factors of the global organization of innovation.

Factors ${ }^{*}$

\begin{tabular}{|c|c|c|}
\hline Factor 1: Reverse transfer of training & & $16 \%$ \\
\hline Performance of the subsidiaries as suppliers of technological capabilities & 0.894 & \\
\hline Performance of the subsidiaries as integrators of technological capabilities & 0.843 & \\
\hline Leading performance of subsidiaries in certain technological capabilities & 0.782 & \\
\hline Factor 2: Autonomy of foreign subsidiaries & & $32 \%$ \\
\hline Purchasing foreign technologies & 0.721 & \\
\hline Hiring specialized consultants in R\&D and innovation & 0.897 & \\
\hline $\begin{array}{l}\text { Creating internal teams focused on the development of R\&D and other } \\
\text { innovative activities }\end{array}$ & 0.886 & \\
\hline Training and continuous training of R\&D staff & 0.858 & \\
\hline $\begin{array}{l}\text { Investment in companies with promising technologies or with the poten- } \\
\text { tial to generate them }\end{array}$ & 0.778 & \\
\hline Know-how exchange with trading partners & 0.734 & \\
\hline Shared technological development with universities and research institutes & 0.739 & \\
\hline Acquisition of start-ups to optimize the efforts in R\&D and innovation & 0.715 & \\
\hline Creation of spin-offs to disseminate technological skills & 0.708 & \\
\hline Licensing patents to the market & 0.701 & \\
\hline Factor 3: Technological duties of foreign subsidiaries & & $82 \%$ \\
\hline Prospecting for scientific and technological trends & 0.945 & \\
\hline Definition of R\&D scope & 0.904 & \\
\hline $\begin{array}{l}\text { Selection of technology partners, including universities and research } \\
\text { institutes }\end{array}$ & 0.874 & \\
\hline Conducting research activities & 0.851 & \\
\hline Carrying out development activities & 0.821 & \\
\hline Non-routine engineering & 0.748 & \\
\hline Customization of products and processes & 0.735 & \\
\hline Project portfolio management & 0.726 & \\
\hline
\end{tabular}

Key to table: ${ }^{\star} \mathrm{KMO}=0.730 ;$ Chi-square $=841,651 ; \mathrm{p}=1 \%$. 
Table 4. Factors of Cooperability.

\begin{tabular}{|c|c|c|}
\hline Factors * & Factor loading & $\begin{array}{c}\text { Cumulative variance } \\
\text { explained }\end{array}$ \\
\hline Factor 1: Cooperability results & & $34 \%$ \\
\hline Generating new products and processes & 0.958 & \\
\hline Generating new marketing methods & 0.877 & \\
\hline Emergence of new technologies & 0.809 & \\
\hline Patent applications deposit & 0.785 & \\
\hline Software registration deposit & 0.761 & \\
\hline Trade mark registration application & 0.745 & \\
\hline Factor 2: Cooperability inputs & & $85 \%$ \\
\hline Adoption of decision criteria & 0.878 & \\
\hline Planning & 0.846 & \\
\hline Monitoring & 0.805 & \\
\hline Knowledge management & 0.794 & \\
\hline Evaluation & 0.768 & \\
\hline Meeting deadlines and budgets & 0.757 & \\
\hline Achievement of objectives & 0.721 & \\
\hline
\end{tabular}

Key to table: ${ }^{*} \mathrm{KMO}=0.908 ;$ Chi-square $=875.319 ; \mathrm{p}=1 \%$.

In Table 4 , it is clear that two factors explain $85 \%$ of the variance of the responses over the dependent variable of cooperability with $1 \%$ significance. Cooperability Results explain (Factor 1) and Inputs of cooperability account for (Factor 2). The highest degree of explanation is related to Factor 2 (51\%) followed by Factor 1 (34\%).

Factor 1 refers to the technological and managerial indicators of the dynamics of cooperation, i.e., the frequency by which the results were achieved in the last three years, considering cooperative $R \& D$ projects. Factor 2 refers to the conditional elements of the dynamics of cooperation, i.e., the frequency by which a formal and systematic management process is adopted during the development of cooperative $\mathrm{R} \& \mathrm{D}$ projects, involving the parent company, subsidiaries and technology partners (Table 4).

The Cronbach's Alpha coefficients were higher than $80 \%$, suggesting that compound variables can be explained by the set of categories from which they are made (Table 5).

Table 5. Cronbach's Alpha coefficient.

\begin{tabular}{|c|c|c|}
\hline Nature of the variable & Composite variables considered in the research model & Coefficient \\
\hline \multirow{2}{*}{$\begin{array}{l}\text { Independent variables of global organization } \\
\text { of innovation }\end{array}$} & Autonomy of foreign subsidiaries* & 0.89 \\
\hline & Technological attributes of foreign subsidiaries ${ }^{*}$ & 0.91 \\
\hline \multirow[b]{2}{*}{ Cooperability-dependent variables } & Cooperability inputs ${ }^{*}$ & 0.96 \\
\hline & Results of cooperability* & 0.97 \\
\hline
\end{tabular}

Key to table: ${ }^{\star}$ Likert scale variables: $1=$ low frequency; 7 = high frequency 
Initially, it is worth mentioning that the prerequisites of the regressions generated were seen as indicating the tests of normality (Kolmogorov-Smirnov and Shapiro-Wilk) and tests of collinearity (VIF) presented in tables 6 and 7.

The coefficients presented in Tables 6 and 7 show the explanatory power of independent variables through factor analysis (Reverse transfer of capabilities, Autonomy of foreign subsidiaries, Technological attributes of foreign subsidiaries, as they have an explanatory level of $82 \%$ as seen in Table 3 ) over dependent variables (Cooperability inputs and results, since they present an explanatory level of $85 \%$ as seen in Table 4). For the regressions conducted after the multicollinearity test (regression 1) we obtained an adjusted R-squared of 95\% for cooperability inputs (Table 6) and $94 \%$ for the results of cooperability (Table 7). We specifically found that reverse transfer of capabilities from foreign subsidiaries to the parent company and technology partners affects the dynamic capability of cooperation in BMNs, with $10 \%$ significance for inputs and results of cooperability (Tables 6 and 7). Therefore, hypothesis $\mathrm{H}_{01}$ was rejected.

Table 6. Regression results considering cooperability inputs as dependent.

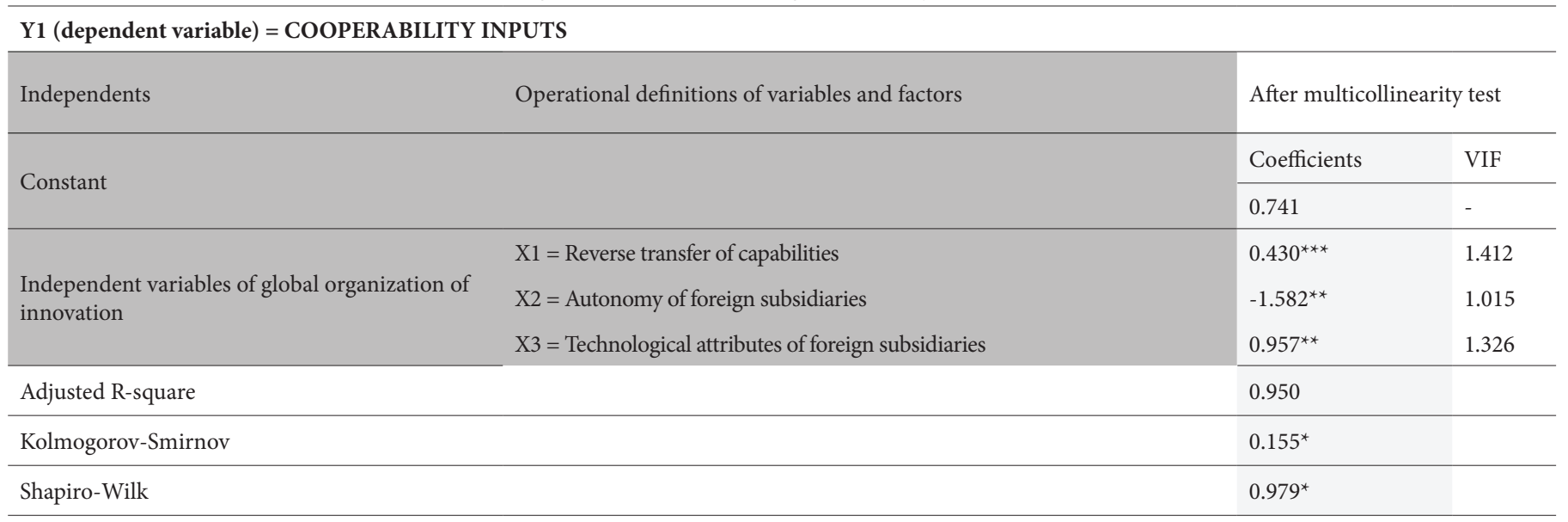

Key to table: ${ }^{*}$ p $1 \% ;{ }^{* *}$ p $5 \% ;{ }^{* * *}$ p $10 \%$.

Table 7. Regression results considering results of cooperability as dependent.

\section{Y1 $($ dependent variable $)=$ COOPERABILITY RESULTS}

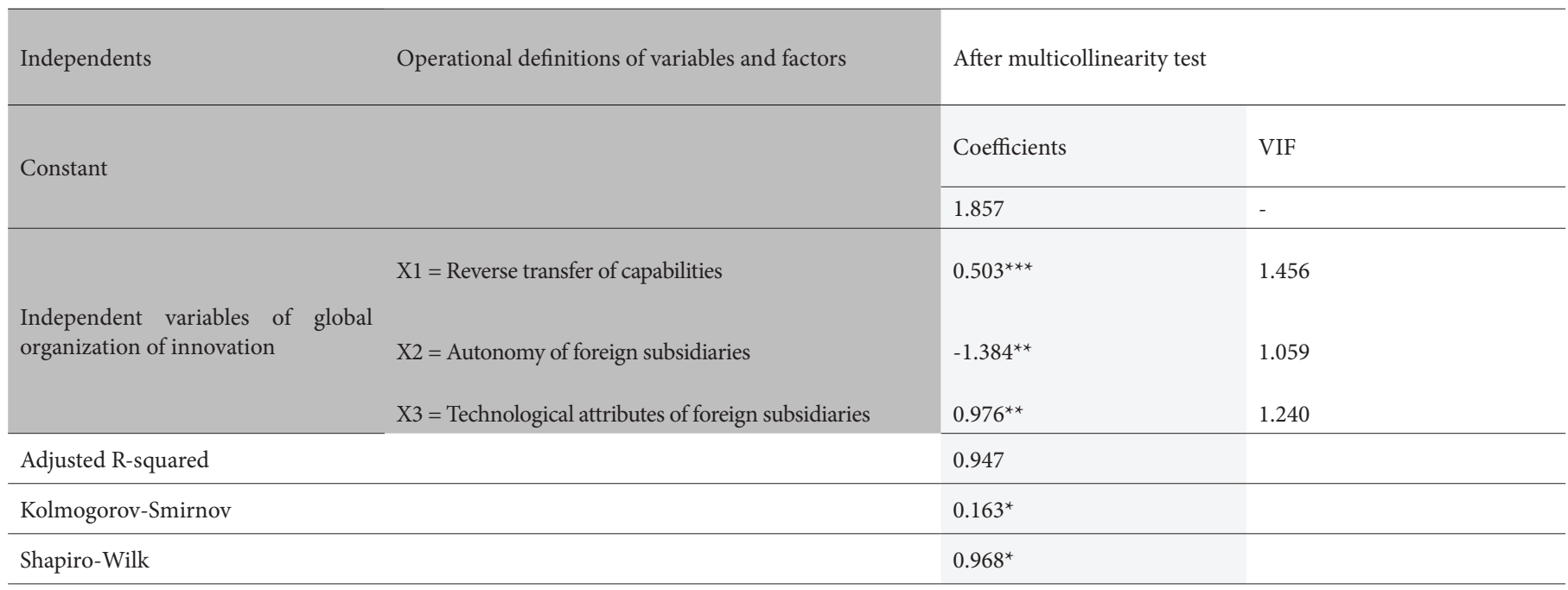

Key to table: ${ }^{*}$ p $1 \% ;{ }^{* *}$ p $5 \%$; ${ }^{* *}$ p $10 \%$. 
The autonomy of foreign subsidiaries proved to be relevant for both inputs and results of cooperability, with 5\% significance (Tables 6 and 7). Thus hypothesis $\mathrm{H}_{02}$ was rejected. Nevertheless, we found a negative correlation, which proved that the greater the autonomy of a foreign subsidiary the lower the frequency of results that translate the managerial and technological efficiency of cooperative R\&D projects involving headquarters, subsidiaries and technology partners. Technological attributes also proved to be relevant for both inputs and results of cooperability, with 5\% significance (Tables 6 and 7). Thus, hypothesis $\mathrm{H}_{03}$ was rejected.

As for cluster analysis (Tables 8 and 9), we observed the formation of three different groupings. Cluster 1 has 33 companies (55\%), of which $60 \%$ are industries, $72 \%$ have up to or over 500 employees and $65 \%$ consider domestic clients to be their most relevant external technology partners (Pearson chi-squared $=10.219 ; \alpha=0.047$; significant at 5\%). Cluster 2 includes 15 companies (25\%), 60\% being service providers, 70\% having between 100 to 499 employees and 55\% considering international suppliers to be their most relevant technology partners, $($ Pearson qui-square $=9,173 ; \alpha=0,032$; significant at $5 \%$ ).
Cluster 3, in turn, contains 12 companies (20\%). 74\% are industries, $60 \%$ have over 500 employees and $65 \%$ consider domestic and international universities and research institutes to be their most relevant technology partners (Pearson's qui-squared $=8.265 ; \alpha=0.028$; significant at $5 \%$ ).

The results shown in Table 9 must be emphasized, as the $t$ test results indicate a difference between representative BMNs in the clusters, suggesting that the variables considered discriminate the global organization of innovation and the dynamic capability of cooperation in each group.

Cluster 1 represents large industrial companies with domestic clients as their principal technology partners. They account for BMNs with a high degree of application of cooperability related managerial inputs, and they transfer capabilities from foreign subsidiaries to parent companies at a medium frequency. Despite achieving average managerial and technological results when it comes to cooperability, granting autonomy and delegation of technological attributes to foreign subsidiaries, the frequency remains low (Tables 8 and 9).

Table 8. Cluster Analysis.

\begin{tabular}{|c|c|c|c|}
\hline Clusters & & Variables & Averages \\
\hline \multirow{3}{*}{$1=33$} & Global organization of innovation & Autonomy of foreign subsidiaries & 1.75 \\
\hline & \multirow{2}{*}{ Cooperability } & Cooperability inputs & 5.37 \\
\hline & & Results of cooperability & 3.56 \\
\hline \multirow{4}{*}{$2=15$} & \multirow[t]{2}{*}{ Global organization of innovation } & Autonomy of foreign subsidiaries & 5.63 \\
\hline & & Technological attributes of foreign subsidiaries & 3.36 \\
\hline & \multirow{2}{*}{ Cooperability } & Cooperability inputs & 2.25 \\
\hline & & Results of cooperability & 2.32 \\
\hline \multirow{2}{*}{$3=12$} & Global organization of innovation & Reverse transfer of capabilities & 5.32 \\
\hline & Cooperability & Results of cooperability & 4.85 \\
\hline
\end{tabular}

Cluster 2 encompasses medium service-provider BMNs with international suppliers as their most important technology partners. These BMNs grant autonomy to foreign subsidiaries at a high frequency, and delegate technological attributes to foreign subsidiaries at a medium frequency. Even so, despite the distinction between autonomy and technological attributes aimed at foreign subsidiaries, we argue that these BMNs still present a low frequency of applications for managerial inputs and technological and managerial results (Tables 8 and 9).
Cluster 3 includes large industrial companies with domestic and international universities and research institutes as their most important technology partners. They have a high frequency of managerial and technological results due to cooperability. Moreover, they are capable of promoting the reverse transfer of capabilities and delegating technological attributes to foreign subsidiaries at a high frequency. These BMNs grant autonomy to foreign subsidiaries and apply cooperability related managerial inputs at a medium frequency (Tables 8 and 9). 
Table 9. $\mathrm{T}$ test between clusters.

\begin{tabular}{|c|c|c|c|c|}
\hline Variables & & $\begin{array}{c}\text { T Test between clus- } \\
\text { ters } 1 \text { and } 2\end{array}$ & $\begin{array}{l}\text { T Test between clusters } \\
1 \text { and } 3\end{array}$ & $\begin{array}{c}\text { T Test between } \\
\text { clusters } \\
2 \text { and } 3\end{array}$ \\
\hline \multirow{3}{*}{$\begin{array}{c}\text { Global organization } \\
\text { of innovation }\end{array}$} & Reverse transfer of capabilities & $-0.873^{\star * *}$ & $2.047^{\star}$ & $-2.410^{*}$ \\
\hline & Autonomy of foreign subsidiaries & $2.364^{*}$ & $1.064^{* *}$ & $0.874^{* *}$ \\
\hline & Technological attributes of foreign subsidiaries & $0.873^{* *}$ & $2.35^{*}$ & $-1.052^{\star *}$ \\
\hline Cooperability & Cooperability inputs & $-1.892^{*}$ & $-0.712^{\star *}$ & $1.741^{* *}$ \\
\hline
\end{tabular}

Key to table: Significance level $1 \%={ }^{*} ; 5 \%={ }^{* *} ; 10 \%={ }^{* * *}$.

\subsection{Proposed Model}

By analyzing the regression models, we can infer that the global organization of innovation affects the dynamic capability of cooperation (cooperability) in Brazilian Multinationals (BMNs). Consequently, research hypotheses $\mathrm{H}_{01}, \mathrm{H}_{02}$, and $\mathrm{H}_{03}$ were rejected, proving that technological attributes of foreign subsidiaries and the reverse transfer of capabilities from foreign subsidiaries to headquarters and technology partners affect the dynamic capability of cooperation in BMNs (cooperability inputs and results).

Furthermore, we found an inverse relationship between the autonomy of foreign subsidiaries and cooperation in BMNs, meaning that the more autonomy is granted to subsidiaries, the less frequent the configuration of inputs and results of cooperability will be.
This indicates the need to develop practices to coordinate actions in foreign subsidiaries with the definition of strategic and operational roles that were previously aligned with the level of autonomy granted.

After performing an aggregate analysis of the clusters presented in Tables 8 and 9 and the hypothesis tests presented in Table 10, we arrived at a Cooperability Model, i.e., a development model for cooperation in BMNs. In this model, the movement from a local towards a more international or global configuration would denote a technological advance (to boost the results of cooperability), and managerial progress, would promote the global organization of innovation from the configuration of autonomy and the technological attributes of foreign subsidiaries, as well as the reverse transfer of capabilities.

Table 10. Results of regression models and hypotheses tests.

\begin{tabular}{|c|c|c|c|c|}
\hline \multirow{2}{*}{\multicolumn{2}{|c|}{$\begin{array}{c}\text { Variables } \\
\text { Cooperability inputs }\end{array}$}} & \multicolumn{2}{|c|}{ Cooperability } & \multirow{2}{*}{ Hypotheses tests } \\
\hline & & Results of Cooperability & & \\
\hline \multirow{3}{*}{$\begin{array}{l}\text { Global } \\
\text { organization } \\
\text { of innovation }\end{array}$} & $\begin{array}{c}\text { Reverse transfer of } \\
\text { capabilities }\end{array}$ & Has a positive effect & $\begin{array}{l}\text { Has a } \\
\text { positive } \\
\text { effect }\end{array}$ & $\begin{array}{l}\underline{\mathrm{H}}_{01} \frac{\text { was rejected. }}{\text { Reverse transfer of capabilities from foreign subsidiaries to the parent }} \\
\text { company and technological partners does not affect the dynamic capability } \\
\text { of cooperation in BMNs. }\end{array}$ \\
\hline & $\begin{array}{c}\text { Autonomy of foreign } \\
\text { subsidiaries }\end{array}$ & Has a negative effect & $\begin{array}{l}\text { Has a } \\
\text { negative } \\
\text { effect }\end{array}$ & $\begin{array}{l}\text { There is no link between the autonomy of foreign subsidiaries and } \\
\text { the dynamic capability of cooperation in BMNs. }\end{array}$ \\
\hline & $\begin{array}{l}\text { Technological } \\
\text { attributes of foreign } \\
\text { subsidiaries }\end{array}$ & Has a positive effect & $\begin{array}{l}\text { Has a } \\
\text { positive } \\
\text { effect }\end{array}$ & $\begin{array}{l}\text { Technological attributes of foreign subsidiaries do not define the } \\
\text { dynamic capability of cooperation in BMNs. }\end{array}$ \\
\hline
\end{tabular}

The variables taken into account in this Cooperability Model were validated by the hypothesis tests (Table 10). As for the configurations of the model (local, international and global arrangements), they were validated by the t-test results (Tables 8 and 9), indicating a difference between representative BMNs in the clusters. It also means that the variables in fact discriminate the global organization of innovation and the dynamic capability of cooperation in each group. External partners with greater relevance for each arrangement were also validated since they have a significance of $5 \%$, as follows: for the local arrangement, partnerships with domestic clients had a Pearson's chi-square $=10.219$ and $\alpha=0.047$; for the international arrangement, partnerships with international suppliers had a Pearson's chi-square = 9.173 and $\alpha=0.032$; finally, for the global arrangement, partnerships with national and international universities and research institutes had a Pearson's chi-square $=8.265$ and $\alpha=0.028$.
By observing the Cooperability Model, we inferred that in the first arrangement a local configuration prevails over the relevance of partnerships with national clients and high application of managerial inputs from the parent company when it comes to the dynamic capability of cooperation. In this configuration, foreign subsidiaries have already transferred capabilities to the parent company. Nevertheless, their autonomy and technological attributes are infrequent. Finally, managerial and technological results occur at a medium frequency due to the dynamic capability of local cooperation (headquarters and domestic clients) (Table 11, Fig. 1).

In the second arrangement, we see the predominance of an international configuration rather than the relevance of partnerships with international suppliers and a considerable concession of autonomy to foreign subsidiaries that have already taken over distinct 
technological attributes. However, these BMNs still show infrequent reverse transfer of capabilities and application of managerial inputs from the parent company concerning the dynamic capability in question. Likewise, managerial and technological results occur at a low frequency due to the international dynamic capability of cooperation (subsidiaries and foreign suppliers) (Table 11, Fig. 1).

Table 11. Model of cooperability in BMNs.

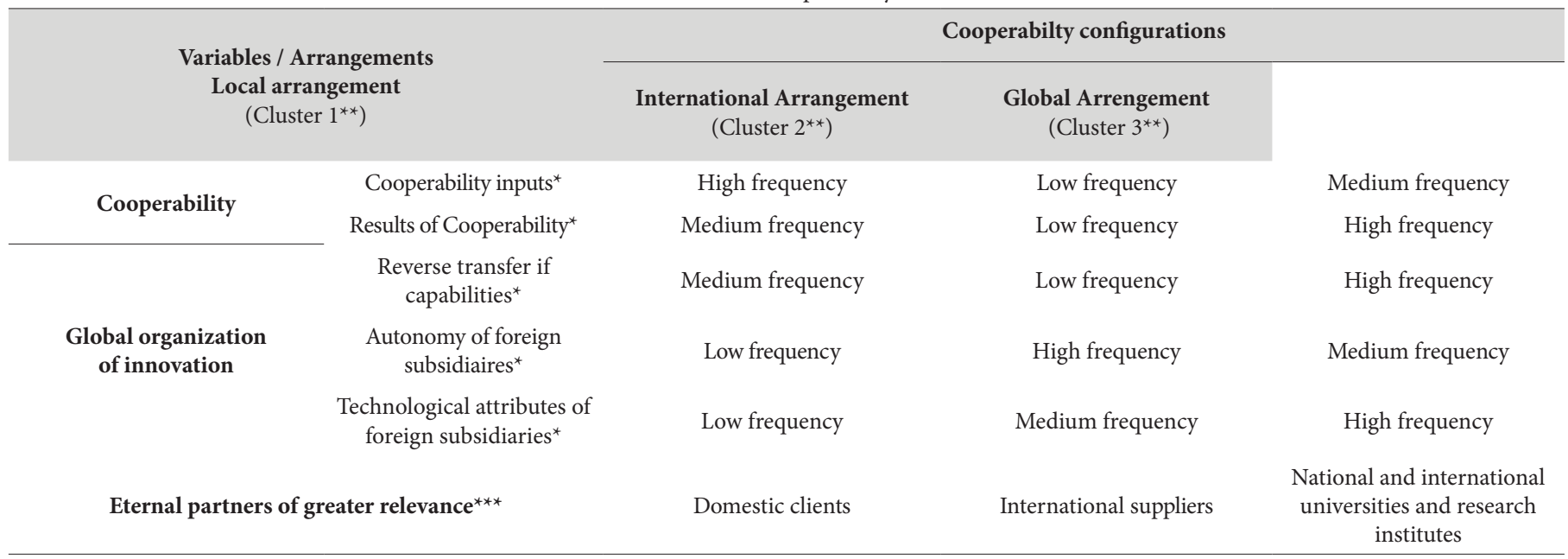

Key to table: ${ }^{*}$ Variables validated by hypothesis tests presented in Table 10 ; ${ }^{* *}$ Test results presented in Tables 8 and 9 indicate a difference between representative BMNs in the clusters, suggesting that the variables certainly discriminate the global organization of innovation and the dynamic capability of cooperation in each group ${ }^{* *}$ Significance of $5 \%$.

Finally, in the third arrangement, a global articulation prevails rather than the relevance of partnerships with national and international universities and research institutes and the high frequency of managerial and technological results from the dynamic capability of local cooperation (headquarters and domestic universities and research institutes) and international cooperation (subsidiaries and international universities and research institutes). In this arrangement, foreign subsidiaries take over the technological attributes and transfer capabilities to headquarters quite frequently. Furthermore, these BMNs grant autonomy to foreign subsidiaries and apply managerial inputs in favor of the dynamic capability of cooperation at a medium frequency (Table 11, Fig. 1).

Attention should be paid to the fact that the sets proposed here are not necessarily a sequential path. In other words, companies with local cooperability can quickly evolve to a global cooperability set to meet their immediate technological needs, and this does not necessarily mean that they have gone through the international set (the case of a born global, for instance). Likewise, hybrid cases are possible to meet the requirements of certain sectors. Moreover, due to the diversity of product portfolios, BMNs in global, international or national sets can demand local, international or global sets.

\subsection{Discussion of Results}

To compete globally emerging multinationals should prospect, obtain and operationalize technology and knowledge dispersed in the international market, which shows a learning opportunity that can put the MNB in a good position (Doz et al., 2001; Andersson et al., 2007). Therefore, BMNs changing their structures to make them more open and flexible, with arrangements that create and share knowledge and technologies in local and/or global contexts (Cantwell et al., 2010), as demonstrated by the proiposed arrangements of local, international and global cooperability (Figure 1), since the most important competitive partnerships the MNBS investigated were established with external sources of knowledge and technology. These are, respectively: domestic customers (local arrangement); international suppliers (international arrangement) and national and international research institutes (global arrangement).

An open and flexible structure requires the multinational systematization of relations of cooperation and continuous integration and knowledge and technological dynamics developed and absorbed into the array, the subsidiaries and the partnerships in local and global contexts (Dunning and Lundan, 2010). In response to the need to promote global integration and local response, multinationals from emerging countries are challenged to align dynamically with autonomy and technological assignments of the subsidiaries. They also have to promote the transfer of training reserves from subsidiaries to the parent company and subsidiaries and place them in international value chains. They also have to transfer knowledge and network technology to enhance performance in the local and global market, offering products, processes and services with higher added value (Yang et al., 2008).

As demonstrated by the proposed cooperability arrangements (Figure 1), it is necessary to develop dynamic relational capabilities (cooperability) through the modification or intentional extension of these arrangements to suit the dynamics of the market and promote global integration and local response. 
To differentiate from traditional multinationals, multinationals from emerging countries, specifically the BMNs, should establish and maintain multifaceted and interactive relations with external partners. The systematization and agility of these collaborative processes will ensure that these companies are able to create dynamics, modify or extend their resource bases by developing and incorporating resources and competencies with partners. On their own, they would not have the necessary resources and stock to keep pace with the technological development of multinationals from developed countries (Helfat et al., 2009).

The BMNs in the study with predominantly local relational capability attributed great importance to competitive partnerships with domestic clients. They also had effective governance mechanisms capable of limiting the transaction costs in the partnerships between headquarters and national technology partners, specifically customers, which positively affected the efficiency of relational capacity and its performance in the generation of knowledge, innovations and new local markets (Figure 1).
The BMNs under study with predominantly international relational capacity attributed great importance to their competitive international partnerships with international suppliers and granted autonomy to strategic foreign subsidiaries (Nobel and Birkinshaw, 1998). Strategic autonomy means that these subsidiaries can set their own R\&D agenda with international suppliers. However, there are negative implications of this arrangement regarding the managerial and technological results of partnerships with external sources in terms of generating knowledge, innovations and new markets.

It should be emphasized that the negative implications of strategic autonomy delegated to subsidiaries are potentially associated with the two situations. First, the integration of highly autonomous subsidiaries tends to be lower due to the difficulty of coordination, leading to the isolation of these branches (Keupp et al., 2011). Second, the capabilities of autonomous subsidiaries are potentially less compatible with the stock of network resources of multinational business. Therefore, incentives and additional investment tend to be more contained, which will negatively affect bargaining power and performance (Both and Schlegelmilch, 2007).

Fig. 1. Description of cooperability model in BMNs.

\begin{tabular}{|c|c|c|c|c|c|}
\hline \multicolumn{2}{|c|}{ COOPERABILITY - LOCAL ARRANGEMENT } & \multicolumn{2}{|r|}{$\begin{array}{l}\text { COOPERABILITY - INTERNATIONAL } \\
\text { ARRANGEMENT }\end{array}$} & \multicolumn{2}{|r|}{ COOPERABILITY - GLOBAL ARRANGEMENT } \\
\hline \multicolumn{2}{|c|}{ 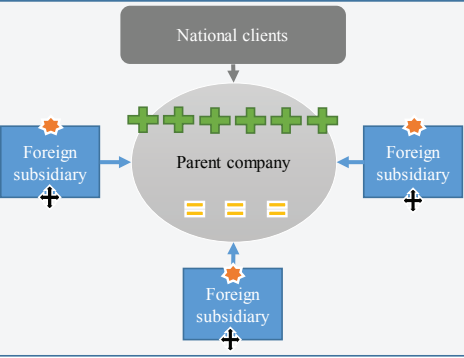 } & & $\begin{array}{l}\text { International suppliers } \\
\text { Parent company } \\
\text { +4+4+4 } \\
\text { subsidiary } \\
+4\end{array}$ & \multicolumn{2}{|c|}{$\begin{array}{ccc}\text { iniversities and research } \\
\text { institutes }\end{array}$} \\
\hline Subtitle & Description - LOCAL ARRANGEMENT & btitle & Description - INTERNATIONAL ARRANGEMENT & Subtitle & Description - GLOBAL ARRANGEMENT \\
\hline & $\begin{array}{l}\text { External partnerships of greater relevance are } \\
\text { formed with national clients. }\end{array}$ & & $\begin{array}{l}\text { ternal partnerships of greater releva } \\
\text { med with international suppliers. }\end{array}$ & & $\begin{array}{l}\text { External partnerships of greater relevance are formed } \\
\text { with national and international universities and } \\
\text { research institutes. }\end{array}$ \\
\hline 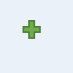 & $\begin{array}{l}\text { Dynamic capability of cooperation is related to a } \\
\text { high level of application of managerial inputs } \\
\text { coming from the parent company. }\end{array}$ & 乌 & $\begin{array}{l}\text { ynamic capability of cooperation is related to a } \\
\text { w level of application of managerial inputs } \\
\text { oming from the parent company. }\end{array}$ & $\$$ & $\begin{array}{l}\text { Dynamic capability of cooperation is related to a } \\
\text { medium level of application of managerial inputs } \\
\text { coming from the parent company. }\end{array}$ \\
\hline$\Delta$ & $\begin{array}{l}\text { Capabilites are transfered from foreign subsidiaries } \\
\text { to the parent company at a medium frequency. }\end{array}$ & $\Delta$ & $\begin{array}{l}\text { apabilites are transfered from foreign subsidiarie } \\
\text { the parent company at a low frequency. }\end{array}$ & 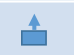 & $\begin{array}{l}\text { Capabilites are transfered from foreign subsidiaries to } \\
\text { the parent company at a high frequency. }\end{array}$ \\
\hline+ & $\begin{array}{l}\text { Autonomy is granted to foreign subsidiaries at a low } \\
\text { level of frequency. }\end{array}$ & + & $\begin{array}{l}\text { Autonomy is granted to foreign subsidiaries at a } \\
\text { high level of frequency. }\end{array}$ & + & $\begin{array}{l}\text { Autonomy is granted to foreign subsidiaries at a } \\
\text { medium level of frequency. }\end{array}$ \\
\hline 急 & $\begin{array}{l}\text { Foreign subsidiaries take over technical attributes at } \\
\text { a low level of frequency. }\end{array}$ & 急 & $\begin{array}{l}\text { eign subsidiaries take over technical attribu } \\
\text { edium level of frequency. }\end{array}$ & 急 & $\begin{array}{l}\text { Foreign subsidiaries take over technical attributes at a } \\
\text { high level of frequency. }\end{array}$ \\
\hline$=$ & $\begin{array}{l}\text { Managerial and technological results occur at a } \\
\text { medium level of frequency due to the dynamic } \\
\text { capability of local cooperation (headquarters and } \\
\text { national clientes). }\end{array}$ & $=$ & $\begin{array}{l}\text { Managerial and technological results occur at a low } \\
\text { level of frequency due to the international dynamic } \\
\text { capability of cooperation (subsidiaries and foreign } \\
\text { suppliers) }\end{array}$ & $=$ & $\begin{array}{l}\text { Managerial and technological results occur at a high } \\
\text { level of frequency due to the dynamic capability of } \\
\text { local cooperation (headquarters and national } \\
\text { universities and research institutes) and international } \\
\text { cooperation (subsidiaries and international } \\
\text { universities and research institutes). }\end{array}$ \\
\hline
\end{tabular}

Finally, the BMNs with global relational capacity attributed great importance to competitive global partnerships with both national and international universities and research institutes. Furthermore, their subsidiaries took on distinct technological assignments (Noorderhaven and Harzing, 2009) and transferred them to headquarters (Schlegelmilch, 2007; Keupp et al., 2011), resulting in mutual access to complementary resources (Petruzzelli, 2011) and the creation of specific assets, such as innovations, technologies and new markets globally (Helfat et al., 2009).
It should also be mentioned that the BMNs with global relational capacity granted operating subsidiaries autonomy. These subsidiaries were able to manage activities previously handled by headquarters. Therefore, they were able to make their own decisions on cooperation with external companies and organizations, promoting the recognition and use of the resources made available by the local systems of innovation. These reflections corroborate the findings of Schlegelmilch (2007), i.e. the greater the operational autonomy of a subsidiary, the greater its ability to explore external sources of innovation and enhance its resource base and performance. 
Finally, it can be concluded that the dynamic relational capability is the convergence between the proposed cooperability arrangements and the needs of global integration and local response. In addition to the BMNs in the study, multinationals from other emerging countries can assess the possibilities for using dynamic relational capacity to flow between one arrangement and another to satisfy specific needs that might require more or less global integration and local response.

\section{Final Remarks}

The main contribution of this study is the proposal of a model for the local, international and global dynamic of cooperation in BMNs and that the shift from a local arrangement to an international or global one would represent a significant leap not only in terms of science and technology but also in management. It would promote a number of positive implications for the innovative performance of BMNs by adopting an intentional governance model that would make the process more systematic and promote shared cooperation between the parties involved.

By performing a cross-analysis of quantitative results, we succeeded in articulating a Cooperability Model. Attention should be paid to the fact that the sets proposed here are not necessarily a sequential path. Likewise, hybrid cases are possible to meet requirements from certain sectors and due to the diversity of product portfolios, BMNs in global, international or domestic sets can demand local, international or global sets.

The limitations of this study are related to the size of the sample, although the sampling process was intentional. Therefore, the conclusions must be carefully considered and generalizations cannot be made concerning the findings. As to future research, we suggest performing an in-depth analysis of cooperability in multinationals from developed economies and conducting quantitative studies comparing determinants of the results of cooperability in developed and developing economies.

\section{References}

Ambos, B., Schlegelmilch, B.B., 2007. Innovation and control in the multinational firm: A comparison of political and contingency approaches. Strategic Management Journal 28, 473-86.

Andersson, U., Forsgren, M., Holm, U., 2007. Balancing subsidiary influence in the Federative MNC: A business network view. Journal of International Business Studies 38, 802-18.

Cantwell, J., Dunning, J.H., Lundan, S.M., 2010. An evolutionary approach to understanding international business activity: The coevolution of MNEs and the institutional environment. Journal of International Business Studies 41, 567-86.

Cronbach, J.L., 1951. Coefficient alpha and the internal structure of tests. Psychometrika, 16, 297-334.

Doz, Y., Santos, J., Williamson, P., 2001. From Global to Metanational. Harvard Business School Press, Boston.
Dunning, J.H., Lundan, S.M., 2010. The institutional origins of dynamic capabilities in multinational enterprises. Industrial and Corporate Change 19, 1225-46.

Dyer, J., Kale, P., 2007. Relational capabilities: Drivers and implications, in: Helfat, C.E., Finkelstein, S., Mitchell, W., Peteraf, M., Singh, H., Teece, D., Winter, S.G., Dynamic Capabilities: Understanding Strategic Change in Organizations. Blackwell, Malden, pp. 65-79.

Ester, R.M., Assimakopoulos, D., Zedtwitz, M.,Yu, X., 2010. Global $\mathrm{R} \& \mathrm{D}$ organization and the development of dynamic capabilities: Literature review and case study of Chinese high-tech firms. Journal of Knowledge-Based Innovation in China 2, 25-45.

Gibbons, R., Henderson, R., 2012. Relational contracts and organizational capabilities. Organization Science 23, 1350-64.

Gulati, R., Puranam, P., Tushman, M., 2012. Meta-organization design: Rethinking design in interorganizational and community contexts. Strategic Management Journal, 33, 571-586.

Hair, J.F., Anderson, R.E., Tatham, R.L., 2007. Análise Multivariada de Dados. Bookman, São Paulo.

Hanaki, N., Nakajima, R., Ogura, Y., 2010. The dynamics of R \& D network in the IT industry. Research Policy 39, 386-99.

Helfat, C.E., Finkelstein, S., Mitchell, W., Peteraf, M., Singh, H., Teece, D., Winter, S.G., 2009. Dynamic Capabilities: Understanding Strategic Change in Organizations. Blackwell, Malden.

Keupp, M.M., Palmié, M., Gassmann, O., 2011. Achieving subsidiary integration in international innovation by managerial " tools". Management International Review 51, 213-39.

Leischnig, A., Geigenmueller, A., Lohmann, S., 2014. On the role of alliance management capability, organizational compatibility, and interaction quality in interorganizational technology transfer. Journal of Business Research, 67, 1049-1057.

Lorenzoni, G., Lipparini, A., 1999. The leveraging of interfirm relationships as a distinctive organizational capability: A longitudinal study. Strategic Management 20, 317-38.

McMahon, D., Thorsteinsdóttir, H., 2013. Pursuing endogenous high-tech innovation in developing countries: A look at regenerative medicine innovation in Brazil, China and India. Research Policy 42, 965-974.

Mudambi, R., Navarra, P., 2004. Is knowledge power? Knowledge flows, subsidiary power and rent-seeking within MNCs. Journal of International Business Studies 35, 385-406.

Nobel, R., Birkinshaw, J., 1998. Patterns of control and communication in international research and development units. Strategic Management Journal 19, 479-98. 
Noorderhaven, N., Harzing, A.W., 2009. Knowledge-sharing and social interaction within MNEs. Journal of International Business Studies 40, 719-41.

Pagano, M., Gauvreau, K., 2004. Princípios de Bioestatística (2a ed.). Pioneira Thomson Learning, São Paulo.

Petruzzelli, M., 2011. The impact of technological relatedness, prior ties, and geographical distance on university - industry collaborations: A joint-patent analysis. Technovation 31, 309-19.

Rabbiosi, L., 2011. Subsidiary roles and reverse knowledge transfer: An investigation of the effects of coordination mechanisms. Journal of International Management 17, 97-113.

Schilke, O., Goerzen, A., 2010. Alliance management capability: an investigation of the construct and its measurement. Journal of Management, 36, 1192-1219.

Teece, D.J., 2007. Explicating dynamic capabilities: The nature and microfoundations of (sustainable) enterprise performance. Strategic Management Journal 28, 1319-50.
Teece, D.J., 2014. A dynamic capabilities-based entrepreneurial theory of the multinational enterprise. Journal of International Business Studies 45, 8-37.

Wuyts, S., Dutta, S., 2014. Benefiting from alliance portfolio diversity the role of past internal knowledge creation strategy. Journal of Management 40, 1653-74.

Yang, Q., Mudambi, R., Meyer, K., 2008. Conventional and reverse knowledge flows in multinational corporations. Journal of Management 34, 882-902.

Zaheer, A., Hernandez, E., 2011. The geographic scope of the MNC and its alliance portfolio: Resolving the paradox of distance. Global Strategy Journal 1, 109-26.

Zohdi, M., Shafeai, R., Hashemi, R., 2013. Influence of relational capabilities on business performance case of: Kermanshah industrial city SMEs. International Research Journal of Applied and Basic Sciences 4, 589-96. 